\title{
«Disse lægevidenskapens høist uegte barn» - kvakksalveri i Tidsskriftet 1900-24
}

\begin{abstract}
Samandrag
Spørsmålet om kven som skal ha lov til å behandle sjuke, har vore debattert i fleire hundreår. I Noreg vart emnet særleg aktualisert i den siste halvdelen av 1800-talet og dei fyrste tiåra av 1900-talet, då den såkalla kvakksalvarlova vart endra fleire gonger. Tilhøvet mellom legar og uautoriserte behandlarar kunne ofte vere anstrengt, og spørsmålet om korleis ein best kunne kjempe mot «Kvaksalver-Uvæsenet» vart i denne perioden mykje diskutert i Den norske lægeforening.
\end{abstract}

Dette spegla seg også i Tidsskriftet, og i perioden 1904-24 vart kvakksalverispørsmålet rekna som ei så viktig sak at det vart oppretta ein eigen spalte om emnet. Med spalten som kjelde er det mogleg å få innblikk i kva legane la i nemninga «kvakksalveri», kva haldningar dei hadde til kvakksalvarvesenet, og kva som var viktige kampsaker.

«Kvakksalveri» famna eit vidt spekter av behandlingsformer. Vern om helsa og velferda til pasientane var utan tvil ein vesentleg motivasjon for legane sitt engasjement i kampen mot «Uvæsenet». Men altruismen var ikkje einerådande, dei hadde òg eigne interesser å forsvare: I ei tid då legane framleis stod på eit relativt svakt fagleg grunnlag, var kampen mot «tjuvar» på medisinen sin marknad også ein kamp for å verne om profesjonen.

\section{Kristine Lillestøl}

lillek78@gmail.com

ME/CFS-senteret

Oslo universitetssykehus, Aker

\section{Aina Schiøtz}

Institutt for samfunnsmedisinske fag

Universitetet i Bergen

For siste gang et ord, nu er jeg tret av striden

og graanet er mit haar nu alt for longe siden.

I 35 aar jeg trofast stod paa vagt

og hørte paa den løgn, der skrevet blev og sagt

om frie lagers virken her rundt $i$ Norges land.

Det var som ei blant Dem, der fandtes cerlig mand.

Med uqvemsord og haan I lager os forfulgte,

mens avindsykens skidne braadd doktoren slet fordulgte.

Utbrotet er henta frå ein klagesong retta mot den norske legestanden, som stod på trykk i Tidsskrift for Den norske loegeforening i 1911 (1). Diktaren var danskfødde Carl Rodian, som i fleire tiår kring 1900 dreiv behandling av sjuke. Dette gjorde han trass $i$ at den einaste medisinskfaglege utdanninga han hadde, var dansk eksamen som farmasøytmedhjelpar (2). Han meinte han hadde fått evna til å lækje sjuke i voggegåve frå Gud, og han kalla seg sjølv «frilæge». I Tidsskriftet vart han derimot fleire gonger titulert som «kvakksalvar», det vil seie som ein «fuskar» i legekunsten (3). Kvakksalvarverksemd var regulert ved lov, og etter det som vert fortalt, gjekk Rodian rett som det var over grensa for det som var tillate, mellom anna ved at han gav seg ut for å vere lege (4-6).

Rodian var langt frå den einaste behandlaren her i landet som praktiserte på kant med lova i denne tida. Vilkåra for slik uautorisert verksemd vart hyppig debatterte, og kvakksalvarlova vart revidert fleire gonger $(7,8)$. Legane deltok òg i ordskiftet - til dømes vart «denne Lægekunstens Vrangside» heftig debattert i Medicinsk Selskab i 1886 .

Bakgrunnen var eit innspel frå Vilhelm Uchermann (1852-1929) som med tilvising til «Kvaksalveriets Tiltagen», tok til orde for ein revisjon av kvakksalvarlova av 1871 (9). Debatten heldt fram i andre fora, og i Tidsskriftet vart kvakksalveriet eit tema allereie frå starten i 1888 , då den berre to år gamle Legeforeininga overtok Tidsskrift for praktisk Medicin. Uchermann vart den fyrste redaktøren i Tidsskriftet, og han fekk som mandat å prioritere hygienisk stoff og «de forskjellige paa dagsorden staaende samfunsspørgsmaal». Mellom desse var nettopp kvakksalverispørsmålet (10).

Særleg frå 1900 og frametter fekk saka mykje omtale i Tidsskriftet, og i 1904 vart det endåtil oppretta ein eigen fast spalte om emnet, med tittelen Kvaksalveri og arkanauvasen. Generalsekretær Rasmus Hansson (1859-1934), som var medredaktør i Tidsskriftet, hadde ansvaret, og spalten vart lagt ned då han gjekk av for aldersgrensa i 1924 (11).

\section{Kvaksalveri og arkanauvæsen}

Denne artikkelen byggjer på Tidsskriftet si handsaming av kvakksalverispørsmålet i perioden 1900-24, med spalten Kvaksalveri og arkanauvcesen som hovudkjelde. Ved oppstarten av spalten oppmoda redaktøren alle kollegene til å sende inn relevante innlegg som kunne tene til å «afsløre den svindel, som drives paa disse omraader» (12).

Resultatet vart ei blanding vesentleg av domsutskrifter, legemiddelannonser og -omtaler, anekdotar om kvakksalvarar og rapportar om korleis kampen mot kvakksalveri gjekk føre seg andre stader. Mange av innlegga var utklipp frå aviser, magasin og fagtidsskrift frå inn- og utland, som ofte fekk tilføya ein redaksjonell kommentar. Nokre legar sende òg inn sjølvskrivne rapportar om aktuelt kvakksalveri, men alt $i$ alt var det berre eit fătal av innlegga som var forfatta av legar utanom redaksjonen. Likevel var legeperspektivet dominerande.

\section{Hovudbodskap}

- Kvakksalverispørsmålet vart hyppig debattert i Noreg i tiåra rundt 1900

- Tidsskriftet hadde frå 1904 til 1924 ein eigen spalte om kvakksalveri, med tittelen Kvaksalveri og arkanauvæsen

- Tidsskriftet si haldning til såkalla kvakksalvarar var sterkt nedlatande

- Vern om pasientar så vel som profesjonsinteresser var viktige kampsaker for legane i striden 
Unntaksvis kom ein og annan kvakksalvar til orde, og nokre andre yrkesgrupper (særleg apotekarane) engasjerte seg i debatten. Pasientane sine haldningar kom berre indirekte fram gjennom legane sine skildringar.

Ei meir omfattande forståing av dette perspektivet krev difor fleire kjelder. På bakgrunn av desse avgrensingane ved materialet har vi hovudsakleg studert legane sitt syn, og spørsmåla vi stiller, er: Kva var «kvakksalveri», sett med norske legar sine auge i denne perioden, og kvifor var legane så opptekne av dette spørsmålet? Kva bilete vart danna av legane sjølve ut frå måten dei handsama kvakksalverispørsmålet på, og kva handla «striden» eigentleg om, sett frå legane si side?

\section{Kvakksalveri}

Materialet gjev ingen eksplisitt definisjon av kva kvakksalveri er. Metodane som ifølgje legane var for kvakksalvarmedisin å rekne, var mange, og kvakksalvarane utgjorde eit fargerikt persongalleri.

Nokre brukte enkle midlar, som «Kattebius-manden» (13) eller danske hr. Madsen, representant for «det 'syndefrie' samfund», som i 1912 behandla folk i Nordland med å smørje dei inn med matolje eller anna feitt (14). Ein omreisande kvakksalvar i Helgeland hadde handspålegging og massasje som sin spesialitet: «Han havde tilfældigvis merket, at han sad inde med en eiendommelig kraft, som udstrømmede fra hans hænder; kraften maatte antagelig være magnetisk eller elektrisk.» (15). Andre kunne ta meir avanserte teknikkar i bruk, til dømes «Røntgenstraaler» og «Kryptoscoplignende kasser» (16). Irisdiagnostikk (17), årelating (18), «den sjette sans» (19) og helbredelse ved bøn (20) vart òg nytta, og frå 1920 kom kiropraktikken (21).

I den gjeldande kvakksalvarlova gav ein ei noko meir avgrensa framstilling av kva som var uønskt behandlarverksemd. Eit viktig punkt var at personar som tok «Syge i Kur», utan å vere autorisert norsk lege eller å ha fătt spesielt løyve frå kongen til å utøve legeverksemd, ikkje skulle bruke titlar som «doktor», «lege» eller på andre måtar få ålmenta til å tru at dei var autoriserte legar (5). Dei skulle heller ikkje behandle farlege epidemiske eller smittsame sjukdomar, med mindre dei fekk særskilt løyve til dette (6). Vidare skulle dei ikkje bruke legemiddel som det var forbode for apotekarar å levere ut til alle, dei måtte ikkje vere omstreifarar, dei skulle ikkje ha utstått straffarbeid, og dei måtte ha opphalde seg i landet i minst tre år (5). Brot på desse reglane skulle straffast, og særleg skjerpande var det dersom ein slik uautorisert person med si behandling påførte den sjuke «betydelig skade på legeme eller helbred».

Hovudpunkta i lova vart òg reflekterte i innlegga i Tidsskriftet. Faren for at pasientar direkte eller indirekte kunne bli

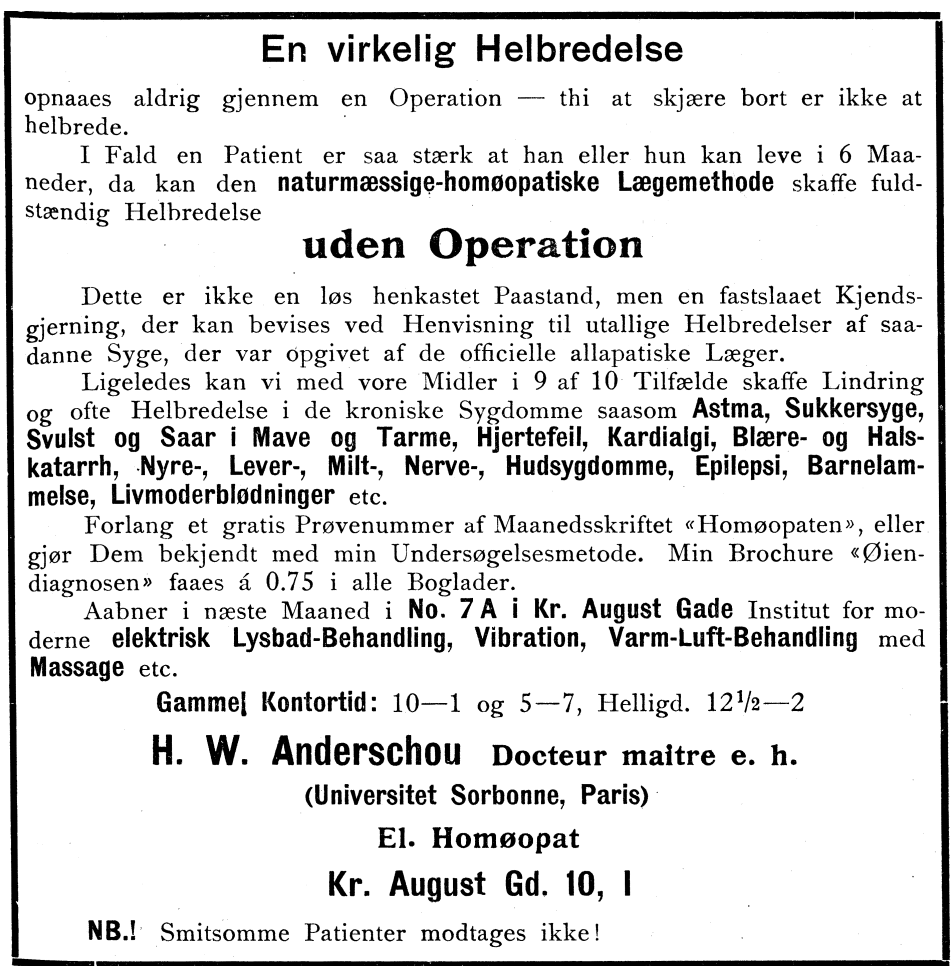

(Avertissem. i "Aftenposten" 6/10 1909 nr. 570).

«Øiendiagnostiker» Anderschou si annonse i Aftenposten vart seinare trykt på ny og latterleggjort i Tidsskriftet

skadde som følgje av ukunnig behandling, var ei av dei viktigaste innvendingane legane hadde mot kvakksalvarverksemd (22). Særleg var dei uroa for uvitug framferd i handtering av pasientar med farlege smittsame sjukdomar. Vidare var det eit gjennomgåande tema at den gjeldande kvakksalvarlova og handhevinga av denne ikkje gav pasientane tilstrekkeleg vern $(22,23)$. Legane var òg provoserte over at heller ikkje lovforbodet mot bruk av legeog doktortitlar vart respektert.

Samla sett ser det likevel ut til at legane opererte med ei brei forståing av omgrepet «kvakksalveri», som gjekk utover reint ulovleg behandlarverksemd. Også heimebundne «bondekvaksalvere» og andre som dreiv tilsynelatande harmlaus praksis utan å utgje seg for å vere legar, vart rekna som kvakksalvarar (22).

Felles for dei ulike kvakksalvarane kan kanskje seiast å vere at dei alle ut frå legane sitt syn representerte «feil» medisin, ei forståing som også er brukt av andre. Omgrepet kvakksalveri er skildra som eit konstruert omgrep som byggjer på at det finst ei oppfatning av kva som er det motsette; at det finst noko som er å forstå som «sann» legekunst i motsetnad til «falsk» (24).

Eit anna og viktig trekk kvakksalvarar har felles, både i dette materialet og elles, er at dei ikkje brukar den nemninga om seg sjølve. Omgrepet er negativt ladd og skapt av ein sterkare motpart.

\section{Arkana}

Det såkalla «arkanauvæsenet» var ei form for kvakksalveri som opptok legane mykje.
Mest grundig var Tidsskriftet sin omtale av dette «Uvæsenet» i åra 1904-06, då spalten inneheldt ein omfattande føljetong om populære arkana.

Arkana var den opphavleg latinske fellesnemninga for såkalla hemmelege legemiddel, det vil seie at innhaldet av preparata vart halde hemmeleg for alle andre enn produsentane sjølve (25). Etter 1888 vart det opna for meir eller mindre fri innførsel av og handel med slike preparat i Noreg, og kring 1900 kom arkanahandelen heilt ut av kontroll. Ei lov som mellom anna skulle gjere det vanskelegare for privatpersonar å drive direkte import av legemiddel, og som opna opp for at «bestemt angivne Lægemidler hvis Sammensætning bliver hemmeligholdt» kunne forbydast, vart vedteken i 1904 (26). Men det tok likevel mange år før ei effektiv regulering kom i stand (7).

Eit kjenneteikn ved arkana var at dei gjerne hadde blømande, poetiske og litt mystiske namn, som «Brahma livs-eliksir», «Wunder Kron-Essenz» og «Babylons fixerier» $(27,28)$. Som namna gjev hint om, var dei fleste preparata importerte (25), men det fanst òg døme på norskproduserte preparat (29). Eit anna særdrag var måten dei vart marknadsførte på $(30,31)$. Det vart ofte hevda at dei var oppfunne eller hyppig brukt av ein geistleg eller kongeleg person. Vidare vart det gjerne lova at midlet skulle vere effektivt mot nesten alle tenkjelege sjukdommar, og at det ville gje fullstendig lækjing for alle som tok det i bruk - slik som «Wunder Kron-Essenz». Midlet var etter plakaten å døme «det sande Bedste for den menneskelige Slægt», og kunne kurere 


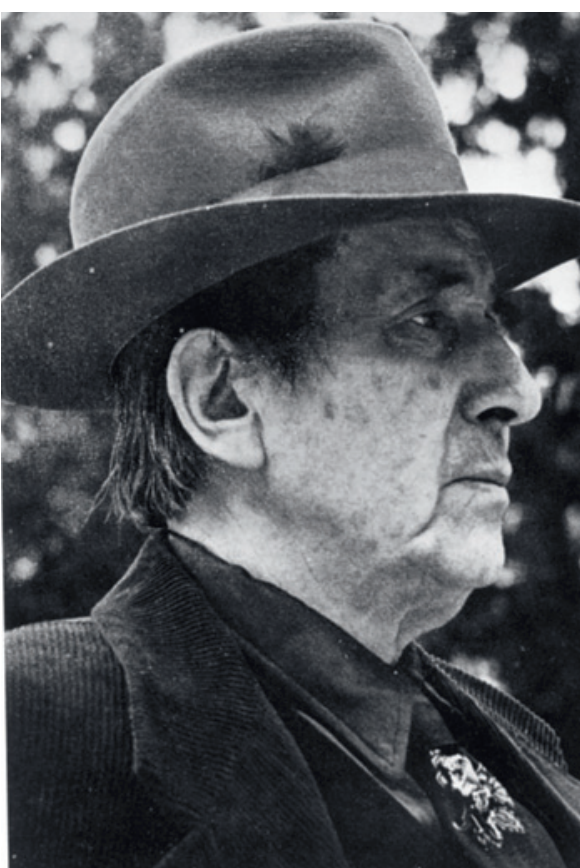

Marcello Haugen (1878-1967), i Tidsskriftet omtala som «den celebre kvaksalver fra Lillehammer» og «fyrbøteren med den 6te og 7de sans», var ein svært populær behandlar (19)

heile spekteret frå menstruasjonsforstyrringar til pest (28).

Eit anna døme var «Dr Campbell's Red Blood forming Capsuloids», framstilt av dr.med. G.E. Dixon, som ifølgje annonsene var «det mest fuldkomne og ideale jernpræarat» (12). Det skulle hjelpe mot blodsjukdommar, forstopping, dårleg fordøying, kronisk bryst- og nervesjukdom samt byrjande tuberkulose.
Elles fanst det òg ikkje-farmakologiske remedier som av legane vart jamstelte med arkana, fordi dei vart marknadsførte på den same måten, og fordi dei vart oppfatta som overprisa i høve til mogleg terapeutisk nytte. Elektriske belte var eit velkjent døme på dette (32). Meir kuriøse var «Magiske, mekanisk-fysiologiske støvler», det vil seie elektrisk ladde støvlar som skulle regulere blodomløpet og elles «forebygge og helbrede alle mulige sygdomme» (33). Skulle det då finnast problem knytte til slike vidunderlege medikament og remedier?

Også når det gjaldt «arkanauvæsenet» var frykt for skade ei vesentleg innvending frå legane. Arkana kunne innehalde giftstoff $i$ større og mindre mengder, og det vart rapportert om dødsfall som følgje av strykninforgiftning etter inntak av «Dr. Kidd's livselixir» (25).

Eit meir vanleg problem med arkana var at dei trass i høge prisar ofte ikkje verka i det heile (30). Sidan innhaldet var hemmeleg, hadde ikkje kjøparen føresetnader for å vurdere den sannsynlege effekten, og kunne dermed heller ikkje vurdere om prisen stod i forhold til innhaldet. Ei anna innvending var at marknadsføringa i mange tilfelle var villeiande. Avskaffing av slik arkanareklame var ei gjennomgåande kampsak i Tidsskriftet (28), og meir generelt var det eit uttalt mål med kvakksalverispalten å avsløre humbug og å spreie informasjon om dette (12).

\section{Avsløringar og moldvarpverksemd}

Det mest systematiske avsløringsarbeidet vart gjort i høve til «arkanauvæsenet». Både i regi av Tidsskriftet og i tilsvarande kampanjar i andre land $(30,31)$ vart det

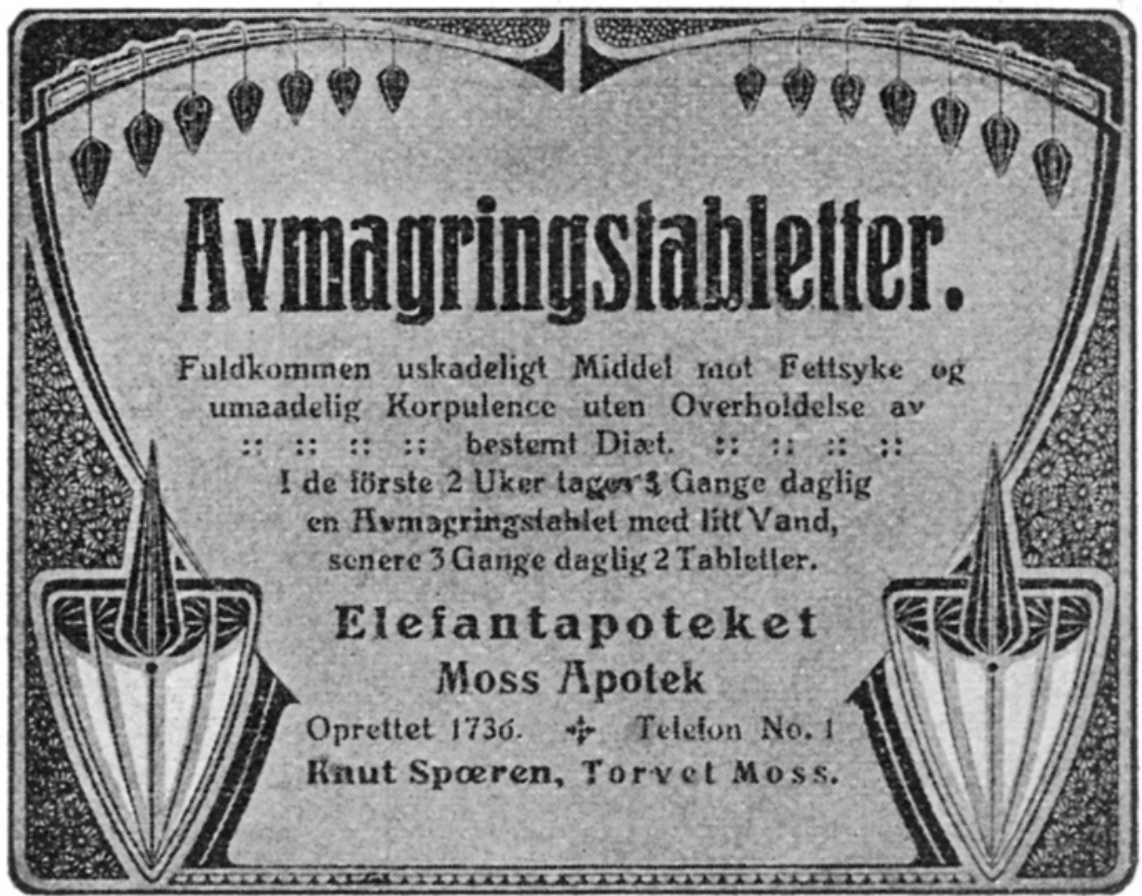

Legane var særleg kritiske til at einskilde apotekarar averterte for arkanaliknande preparat, som i dette tilfellet

utført grundige analyser der føremålet var å avmystifisere dei hemmelege preparata.

Dette gjorde ein ved å avsløre både den kjemiske samansetninga av arkana, den reelle identiteten til opphavsmennene og den eigentlege verdien av preparata - alt for å underminere makta til produsentane og aller helst få preparata forbodne (31).

Tidsskriftet sine talrike rapportar om slike analyser baud på mange interessante funn. Mellom anna synte det seg at dei førnemnde «Dr. Campbells Red Blood forming Capsuloids», som jo skulle vere eit reint og fullkomment jernpreparat, i røynda var «et sterkt forurenset præparat (...), en mørkebrun masse, af en modbydelig lugt af harskt fedt» (12). Prisen på Capsuloids var 2,50 kroner per øskje, medan ein etter analysen kom fram til at 7 øre ville vere ein meir passande pris. Det vart òg kjent at opphavsmannen til Capsuloids, dr.med. G.E. Dixon, ikkje på nokon måte var dr.med.

Også andre former for kvakksalveri vart gjenstand for Tidsskriftet sine granskingar. Ein gong fekk redaktør Hansson ein medarbeidar til å utgje seg for å vere pasient og å oppsøkje Kristiania-kvakksalvaren Anton Nielson - «specialist i mave- og tarmsygdomme» - for konsultasjon (34).

Bakgrunnen var at det gjekk rykte om at kvakksalvaren hadde skaffa seg røntgenapparat. Dette ville Tidsskriftet vite meir om, og den utsende medarbeidaren Hr. B. dikta opp nokre mageplager. Undersøkinga, som ikkje uventa inkluderte ei form for «gjennemlysning», vart deretter skildra i detalj (34). Nielson kom ikkje heldig ut og sende inn eit rasande tilsvar: «Men at en norsk læge vil i den grad glemme sin stand at han nedlader sig til simpel spionage, spiller patient her hos mig og derved skaffer sig vaaben til at frarive meg min og min families næring, det skulde man neppe troet» (16). Han råda legane til å «undlade dette slags muldvarp arbeide der dog bliver Røntgenbelyst og vist $\mathrm{i}$ al dets tarvelighed». Og ein ting angra han på: Han skulle ha brukt sterkare straum $\mathrm{i}$ «behandlinga» av Tidsskriftet sin utsende spion!

\section{Legane - ein stand av gentlemen?}

Slike motåtak frå kvakksalvarar var sjeldan vare. Inntrykket Tidsskriftet elles gjev, er at det var dei «eksaminerte» medisinarane som var «ekte» og opplyste legar, medan kvakksalvarane var uopplyste og «falske». Det var legane som stilte dei rette diagnosane og visste kva som var god og dårleg behandling, medan kvakksalvarane og arkanaprodusentane sine teoriar vart framstilte som «pseudovidenskabelig sniksnak» (22).

Karakteristikken «disse lægevidenskapens høist uegte barn» vart i utgangspunktet brukt om kiropraktorane, mellom anna fordi dei hadde ei anna sjukdomsforståing og mykje kortare utdanning enn legane (35). Men sitatet kan òg seiast å uttrykkje Tidsskriftet si haldning til kvakksalvarane sett under eitt. 
I sitt eige bilete var legane meir høgareståande vesen enn kvakksalvarane også på andre område enn det reint vitskaplege. Særleg tydeleg kom dette fram i utsegna til legen som oppsøkte Marcello Haugen (1878-1967) for å ta metodane og dei spesielle evnene hans i nærare augesyn: «Det er liksom lit ufornemt at ta en kvaksalver (...) for alvor, selv om det bare er til undersøkelse. Det er kanskje en rest av standsstolthet hos mig» (19).

Medan kvakksalvarane i Tidsskriftet vart skildra som frekke, uærlege og pengegriske sjarlatanar, som «samvittighetsløse kjæltringer, som spekulerer i menneskeliv»(36), framstod legane som heiderlege «riddarar» som ville verje om pasientane og interessene deira. Dei var opptekne av å markere avstand til kvakksalvarane, og det skulle ikkje meir til for å provosere ein lege enn at lege- og kvakksalvarannonser hamna ved sida av kvarandre i avisene: «Hvor smigrende for vore læger, for et par doctores medicinae, for sanatorier osv, at kunne staa sammen med pinkpiller og Carl Rodian! Ja, er ikke sligt en skandale, en skamplæt for en lægestand, vet ikke jeg!» (37).

Avstanden mellom lege og kvakksalvar var likevel ikkje alltid like stor som det Tidsskriftet ville ha det til. Begge partar kunne ha lite effektive behandlingsformer og til dels bruke same metodar, til dømes arkanapreparat (38). Og litt pinleg var det nok då apoteker Størmer i 1904 påpeika at Tidsskriftet sjølve hadde reklamert for førnemnde Capsuloids - som redaktøren så stolt hadde hevda å ha avslørt (39).

Innimellom finn vi då òg spor av sjølvransaking frå legane si side. Fleire gonger vart det mana til orden i eigne rekkjer, mellom anna vart det oppmoda til at legar aldri måtte føreskrive legemidlar som vart annonserte i dagspressa (40).

Nokre frykta at kvakksalvarane si verksemd ville medføre «moralsk infektion» av svake medlemmer av legestanden (22). Ein lege vart av kolleger skulda for å drive «kvaksalvermæssig» verksemd då han i legespalten i Fri presse kom med eit ikkje vitskapleg fundert behandlingsråd mot fregner (41): «Masser morgen og aften det fregnede parti med litt urin.» Han la til: «Dette kan jo gjøres i stilhed, saa ingen vet om det.»

Bodskapen om slik legeåtferd var klar: «Lad os gjøre hva vi kan, for at vor stand kan vedblive at være, hva den har været, en stand af gentlemen, og lad os vise dem, som ikke vil optræde som det sømmer sig vor stilling, at vi ikke stilltiende vil taale en adfærd, som kun kan drage vor stands anseelse ned i det almindelig omdømme» (42).

Men som vi allereie har sett, var meiningane delte om legane faktisk lukkast med å leve opp til sine gentlemanideal. Det var ikkje berre kvakksalvarar som følte seg ærekrenkte av legane sin krasse stil og hånlege tone. Både juristar og apotekarar kjende

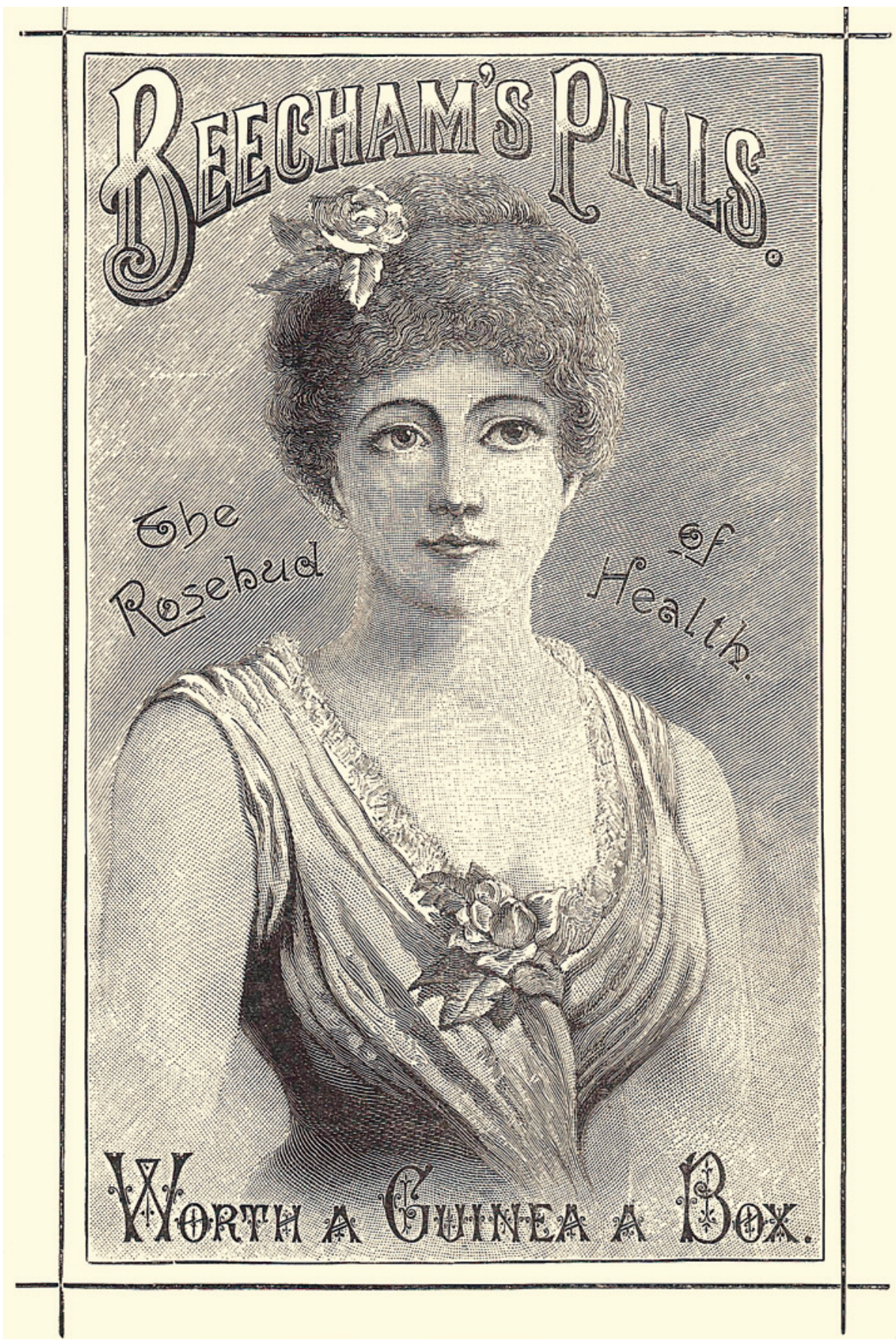

Dei fleste arkana var importerte. Eit «vidunderpreparat» som vart særleg hissig marknadsført gjennom fleire tiår, var «Beecham's pills»

seg trakka på i den oppheita debatten, og det kom oppmodingar frå fleire hald om at legane måtte roe ned og føre den verbale kampen på ein meir avdempa og sakleg måte $(39,43)$.

\section{Kvakksalveriet - ein nyttig fiende?} Legane hadde mange grunnar til å ergre seg. Det var ikkje berre pasientane som kunne bli skadelidande av ei ineffektiv kvakksalvarlov og eit kvakksalvarvesen som stadig breidde om seg, men også legane sjølve. Sjølvbiletet deira vart truga gjennom arkanareklame som lova kur for folk som «i aarevis har søgt de dygtigste læger uden spor af nytte» (22), og kiropraktorbrosjyrer inneheldt mange «bedrøvede og indignerte henvisninger til lægekunstens avmagt og feilfuldhet» (35).

Det er heller ikkje til å kome frå at dei mest populære og «profesjonelle» kvakksalvarane var reelle konkurrentar som tok pasientar og dermed inntekter frå legane. Om ein «kvindelig «mirakeldoktor» i Aafjord» vart det til dømes fortalt at ho hadde faste kontordagar på tre ulike stader i bygda, i tillegg til at ho vitja to nabobygder jamnleg, og «lange køer stod utenfor hendes residens fra tidlig paa formiddagen til sent paa kveld» (44). Så kan- 
skje var Carl Rodian inne på noko då han antyda at «avindsyken» var noko mange legar kjende på (1)?

Andre har hevda at kampen mot kvakksalveri og arkanahandel faktisk tilførte legane noko positivt. Historikaren Riitta Oittinen, som har studert ein tilsvarande konflikt mellom legar og kvakksalvarar i Finland, slår fast at «Humbug made a good enemy» (31). Med dette meiner ho at legestanden, som i denne tida framleis hadde lite å tilby av terapeutiske hjelperåder, fekk «hjelp» av kvakksalveriet til å definere sin eigen identitet. Dei ynskte å framstå som ein motpol og noko betre enn kvakksalvarane. Tilsvarande kunne nok kampen mot kvakksalveriet vere «nyttig» også for legeprofesjonen her til lands, som framleis var relativt svak dei fyrste tiåra av 1900-talet (45).

I alle fall er det sikkert at for Legeforeininga sentralt var kampen mot kvakksalveriet også ein kamp for å verne om eigeninteressene. Perioden vi her har studert, med eit sterkt søkelys på kvakksalveri i Tidsskriftet, fell saman med Rasmus Hansson si tid som generalsekretær i Legeforeininga (1900-24). Hansson vart skildra som ein uvanleg iherdig fagforeiningsmann som var utrøytteleg i arbeidet med «å samle lægestanden til en enhet for å trygge dens kår» (11). Som talerøyr for Legeforeininga var det naturleg at Tidsskriftet såg det som si oppgåve å verne standsinteressene mot det trugsmålet kvakksalveriet faktisk utgjorde.

Om eit slikt søkelys på profesjonskamp, og meir generelt ei svært negativ haldning til kvakksalvarar, var å finne hjå legane kringom i landet elles, er meir uvisst. Som nemnt inneheldt kvakksalverispalten relativt få lesarinnlegg frå legar utan tilknyting til den sentrale leiinga i Legeforeininga og Tidsskriftet.

Det er tidlegare vist at sjølv om Legeforeininga si «offisielle» haldning til kvakksalveri var særs negativ, var oppslutnaden blant legar i den konkrete kampen mot kvakksalveriet på landsbasis liten. Mellom anna vart dette reflektert i ei spørjeundersøking frå 1888, der legane i heile landet skulle kartleggje den lokale førekomsten av kvakksalveri (46).

Vi veit òg at legane ute i distrikta sjeldan gjekk så langt som til å prøve å få kvakksalvarar stilte for retten (47). Dels var det vel fordi dei visste at det sjeldan førte fram, dels var dei nok redde for sjølve å bli upopulære blant «Almuen». Kan hende var ikkje tilhøvet mellom lege og kvakksalvar alltid så anstrengt heller. I alle fall ser det ut til at dei stort sett let kvarandre i fred (47).

\section{Ektefødde born}

Kvakksalveri var eit vidt omgrep slik det vart nytta i Tidsskriftet i perioden 1900-24, og omfatta mange former for behandling av sjuke. Felles for dei alle var at dei vart framstilte som «feil» medisin, og legane var uroa over skadeleg behandling og svindel frå kvakksalvarane si side.

Samla sett er det tydeleg at Tidsskriftet sin redaktør og legane i sine lesarinnlegg ynskte å markere klar avstand til kvakksalvarane, og i til dels kvasse ordelag gjorde sitt beste for å framstille seg sjølve som ekte representantar for legekunsten. Kven som i røynda var legevitskapen sine «ektefødde» born i denne perioden, var likevel ikkje alltid godt å seie.

\section{Kristine Lillestøl (f. 1978)}

er assistentlege ved ME/CFS-senteret, Oslo universitetssykehus, Aker. Ho har ph.d.-graden fra Universitetet i Bergen 2010, om matrelaterte mageplager.

Ingen oppgjevne interessekonfliktar.

\section{Aina Schiøtz (f. 1947)}

er dr.philos. og professor i medisinsk historie ved Institutt for samfunnsmedisinske fag, Universitetet i Bergen. Ho har særleg arbeidd med problemstillingar innanfor profesjonshistorie, samfunnsmedisin og rettsmedisin.

Ingen oppgjevne interessekonfliktar.

\section{Litteratur}

1. «Frilæge» Carl Rodians klagesang. Tidsskr Nor Lægeforen 1911: 31: 638-9.

2. «Klok mand» eller «klok kone» søkes. Litt om kvaksalverstørrelserne. Tidsskr Nor Lægeforen 1911; $31: 259$

3. Aasen I. Norsk Ordbog med dansk forklaring Fjerde uforandrede udgave. Kristiania: Cammermeyers forlag, 1918

4. Michelsen G. En kvaksalver, som har «medicinsk og kirurgisk behandling» - «engelsk sygebehandling» og driver salg af medikamenter. Tidsskr Nor Lægeforen 1905; 25: 379-81.

5. Lov om Forandring i Kvaksalverlovgivningen. 29 April 1871

6. Lov indeholdende Forandring i og Tillæg til Lov af $29 \mathrm{de}$ April 1871 om Forandring i Kvaksalverlovgivningen. 6. juni 1889

7. Berner JH. Den norske lægeforening 1886-1936. Festskrift i anledning av foreningens 50 års jubileum. Oslo: Den norske lægeforening, 1936 : 303-06.

8. Ot.prp. nr. 39 (1936). Lov om innskrenkning i adgangen for den som ikke er norsk læge eller tannlæge, til å ta syke i kur.

9. Forhandlinger i Det norske medicinske Selskab i Kristiania 1886. Kristiania: Det Steenske Bogtryk keri, 1887: 35-42.

10. Schiøtz A. Vårt fag - likeså meget en kunst som en vitenskap - Tidsskriftet 1881-1906. Tidsskr Nor Laegeforen 2006; 126: 9-13.

11. Berner JH. Rasmus Hansson (nekrolog). Tidsskr Nor Lægeforen 1935; 55: 1-3.

12. Kvaksalveri og arkanauvæsen. Tidsskr Nor Lægeforen 1904; 24: 113-9

13. Kattebius-manden. Abracadabra. Intet nyt under solen. Tidsskr Nor Lægeforen 1906; 36: 282-3.

14. Kvaksalveri og «spirituøse» mirakelmakere i Nordland. Tidsskr Nor Lægeforen 1912; 32: 524-5.

15. Berg A. Enkelte træk fra kvaksalveriet nordpaa. Tidsskr Nor Lægeforen 1906; 26: 721-4.

16. Nielson A. Et bes $\varnothing \mathrm{g}$ hos «specialist i mave- og tarmsygdomme», bændelormdoktoren Anton Nielson. Tidsskr Nor Lægeforen 1907; 27: $101-3$

17. «Øiendiagnostiker» Anderschou i et engelsk sportsblad. Tidsskr Nor Lægeforen 1911; 31: 208-9.

18. Kvaksalver dømt for aarelating. Tidsskr Nor Lægeforen 1912; 32: 819-21.
19. Manden med den sjette sans - Marcello Haugen Et bidrag til tidens overtro og kulturstandpunkt. Tidsskr Nor Lægeforen 1913; 33: 1126-34.

20. «Mirakler» i Stavanger. Tidsskr Nor Lægeforen 1915: 35: 129-33.

21. «Chiropraktisk» kvaksalver i Norge. Tidsskr Nor Lægeforen 1921; 41: 892-3.

22. Arnesen, H. Kvaksalverondet. Tidsskr Nor Lægeforen 1902; 22: 487-98

23. Eide E. Kvaksalverne og paatalemyndigheden. Tidsskr Nor Lægeforen 1903; 23: 156-63.

24. Ling S. Kärringmedicin och vetenskap. Läkare och kvacksalverianklagade i Sverige omkring 1770 - 1870. Uppsala: Uppsala universitet, 2004 $13-15$

25. Ot.prp. nr. 14 (1903-1904). Angaaende udfærdigelse af en lov om indførsel af apotekervarer samt om handel med gifte og arkana.

26. Lov om Indførsel af Apothekervarer samt om Handel med Gift og Arkana.16. Mai 1904

27. Kvaksalveri og arkanauvæsen. Tidsskr Nor Læge foren 1906; 26: 424-8

28. Kvaksalveri og arkanauvæsen. Tidsskr Nor Lægeforen 1906; 26: 504-8.

29. Størmer G. Det nye norske jernpræparat fercao Tidsskr Nor Lægeforen 1904; 24: 385-7.

30. Thunberg T. Om bedrägliga läkemedel och läkemetoder jämte redogörelse för några i vårt land utbjudna läkemedel. Uppsala: Byrån för upplysning om läkemedelsannonser, 1906

31. Oittinen R. Health, horror and dreams for sale: Patent medicine and quackery in prewar Finland. I: Jütte R, Eklöf M, Nelson MC, red. Historical aspects of unconventional medicine. Approaches, concepts, case studies. Sheffield: European Association for the History of Medicine and Health Publications, 2001: 119-38.

32. Scharffenberg J. Kvaksalver- og beltereklamer. Tidsskr Nor Lægeforen 1911; 31: 205-6.

33. «Magiske, mekanisk-fysiologiske støvler». Bedragne millionærer. Humbugen leve! Tidsskr Nor Lægeforen 1906: 26:354-5.

34. Herr B. En konsultation hos «specialist i maveog tarmsygdomme», bændelormdoktoren Anton Nielson. Tidsskr Nor Lægeforen 1906; 26: 896-8.

35. «Chiropraktikerne» utenlands og hjemme. Tidsskr Nor Lægeforen 1924: 44: 318-20.

36. Aaser P. Tæringskure [«concumption cures») i Amerika. Tidsskr Nor Lægeforen 1912; 32: 76

37. Aall C. Kvaksalverannoncer og lægers avertissementer i dagsaviserne. Tidsskr Nor Lægeforen 1903; 23: 631-2.

38. Poulsson E. Notis om et arkanum - «Pastor Königs Nervenstärker». Tidsskr Nor Lægeforen 1910; 30: 654-5.

39. Størmer G. Arkanauvæsenet og reklamering af arkana. Tidsskr Nor Lægeforen 1904; 24: 1020-3.

40. Forskriv aldrig lægemidler, som annonceres i dagspressen! Tidsskr Nor Lægeforen 1922; 42: 336.

41. Læger og kvaksalvere. Tidsskr Nor Lægeforen 1909; 29: 30-1.

42. X. «Medicinsk geschäft». Tidsskr Nor Lægeforen 1903; 23: 631

43. Lund 0 . Kvaksalverne og paatalemyndigheden. Tidsskr Nor Lægeforen 1903; 23: 279-83.

44. Kvindelig «mirakeldoktor» i Aafjord. Tidsskr Nor Lægeforen 1924; 44: 359-60.

45. Schiøtz A. Folkets helse - landets styrke 1850-2003. Det offentlige helsevesens historie 1603-2003. Bd. 2. Oslo: Universitetsforlaget, 2003.

46. Til belysning af kvaksalveriets udbredelse i Norge. Indberetning fra Den norske lægeforenings sekretær. Tidsskr Nor Lægeforen 1891: 11: 60-71.

47. Lillestøl K, Schiøtz A. «Bedre at have en Kvaksalver end to Doktorer»? Distriktslegar og kvakksalvarar i Nordfjord og på søre Sunnmøre 1850-1900. I: Årbok for Nordfjord. Sandane: Nordfjord Sogelag, 2008: 48-79.

Mottatt 15.10. 2011, første revisjon innsendt 30.10 2011, godkjent 3.11. 2011. Medisinsk redaktør Anne Kveim Lie. 